\title{
WATER QUALITY ANALYSIS OF CODE RIVER BASED ON METAL AND NONMETAL PARAMETERS USING HEAVY METAL POLLUTION INDEX
}

\author{
M. Widyastuti', Galih Dwi Jayanto ${ }^{2}$, Muhammad Ridho Irshabdillah ${ }^{1}$ \\ 1Jurusan Geografi Lingkungan, Fakultas Geografi, Universitas Gadjah Mada \\ 2Magister Perencanaan Pengelolaan Pesisir dan Daerah Aliran Sungai, Fakultas Geografi, \\ Universitas Gadjah Mada \\ Jl. Kaliurang, Sekip Utara, Bulaksumur, Sleman, Yogyakarta, 55281, Indonesia \\ e-mail: m.widyastuti@geo.ugm.ac.id
}

Received: 25 September 2020, Repaired: 30 December 2020, Approved: 07 May 2021

\begin{abstract}
Abstrak
Sungai Code merupakan salah satu sungai di DIY yang banyak dipengaruhi aktivitas manusia yang menghasilkan limbah dan menjadi beban pencemaran. Indeks pencemaran logam berat belum banyak digunakan di Indonesia. Dalam penelitian ini, penentuan nilai indeks tidak hanya diterapkan untuk parameter logam berat saja, namun juga diterapkan untuk parameter bukan logam. Tujuan penelitian ini adalah 1) mengkaji kualitas air sungai, baik parameter logam berat maupun parameter bukan logam (parameter yang mencirikan limbah domestik), 2) menilai indeks kualitas air menggunakan heavy metal pollution index (HPI) atau indeks pencemaran logam berat, dan 3) evaluasi kualitas air berdasarkan indeks kualitas air. Data diperoleh dari hasil pemantauan kualitas air sungai secara temporal oleh Dinas Lingkungan Hidup dan Kehutanan DIY. Parameter logam berat meliputi $\mathrm{Fe}, \mathrm{Cu}, \mathrm{Cd}, \mathrm{Cr}, \mathrm{Pb}$, sedangkan parameter bukan logam meliputi $\mathrm{BOD}$, COD, TSS, amonia, minyak lemak dan bakteri coliform total. Indeks kualitas air sungai dinilai menggunakan HPI untuk parameter logam, non logam, dan seluruh parameter. Baku mutu kualitas air mengacu Peraturan Gubernur Nomor 20 Tahun 2008. Hasil penelitian menunjukkan, nilai indeks HPI untuk parameter logam termasuk kelas sangat baik $(2,52)$, sedangkan parameter bukan logam termasuk kelas buruk $(55,04)$. Nilai indeks HPI untuk seluruh parameter kualitas air sungai termasuk kelas sangat baik $(3,94)$. Berdasarkan nilai indeks kualitas air (HPI), kondisi kualitas air Sungai Code mempunyai status yang lebih baik dengan penggabungan parameter logam dan non logam.
\end{abstract}

Kata kunci: HPI (Heavy Metal Pollution Index), kualitas air, limbah domestik, logam berat, Yogyakarta

\begin{abstract}
Code is one of the rivers influenced by a large number of waste-generating human activities in Yogyakarta, Indonesia. Despite continued discharges of pollution loads from anthropogenic waste, the heavy metal pollution index (HPI) - a water quality index assessing heavy metal ions present in a body of water - remains nationally underutilized. The research was intended to 1) analyze the river water quality based on metal and nonmetal parameters typical of domestic waste, 2) calculate HPI using either and both parameters, and 3) evaluate the resultant water quality status. The water quality data were the products of temporal river monitoring conducted by the Forestry and Environmental Office for Yogyakarta. The heavy metal parameters included $\mathrm{Fe}, \mathrm{Cu}, \mathrm{Cd}, \mathrm{Cr}$, and $\mathrm{Pb}$, while the nonmetal parameters were BOD, COD, TSS, ammonia, oil and grease, and total coliforms. Each parameter value was compared with the water quality standard issued in Governor Regulation No. 20/2008. The results showed that the HPI composite of heavy metal parameters classified the river water quality as excellent (2.52), whereas the one representing nonmetal parameters indicated bad quality (55.04). Nevertheless, based on the HPI composed of all parameters, the quality fell into the category excellent (3.94).
\end{abstract}


Consequently, when all metal and nonmetal parameters are combined into the HPI calculation, the river shows a better water quality status.

Keywords: HPI (Heavy Metal Pollution Index) water quality, domestic waste, heavy metal, Yogyakarta.

\section{INTRODUCTION}

Rivers are among surface water resources with great potentials that vast communities rely on as raw water sources for drinking and economic activities, such as industry, fishery, and agriculture (Imroatushshoolikhah et al., 2014). For instance, Ranau River in Rantau Kopar, Riau-Indonesia, supplies Duri Water Utility Services (Gusril, 2016), and several rivers on the footslope of Mount Tambora, Nusa Tenggara Barat-Indonesia, provide irrigation water for sugarcane plantations (Adhitya et al., 2017). Raw water quality depends on the river's chemical, physical, and biological properties, which are sensitive to many factors, including anthropogenic effects. Increased human activities and diverse lifestyles of urban communities around rivers create varying amounts of stress on water quality and, eventually, threaten the sustainability of the river functions (Mahyudin et al., 2015).

Similarly, population pressure on Code River in Yogyakarta, Indonesia, is likely to increase, especially on the segment that traverses the urban areas. It leads to decreased water quality and even pollution. River water quality studies in urban regions provide a basis for identifying and formulating appropriate river management by dividing this body of water into segments according to their respective water quality problems (Pohan et al., 2017). Segments showing deteriorating quality cannot be utilized for their designated uses in an otherwise uncontaminated condition (Ali et al., 2013).

Pollution loads released into rivers flowing across urban areas mainly come from domestic waste. Domestic wastewater, or gray water, is generated in households from kitchen sinks, baths, laundry uses, and house cleaning (e.g., floor mopping) but excludes wastewater from toilets (Ester Suoth \& Nazir, 2016). If disposed of directly into water bodies without receiving prior treatments, it can lead to water pollution. Apart from containing organic, inorganic, and gaseous chemicals (Ester Suoth \& Nazir, 2016), it can also carry heavy metals. Their presence in the domestic wastewater (i.e., concentrations and distributions) depends on the characteristics of detergents used in washing, as confirmed by research findings in San Francisco Bay, California (Jenkins \& Russell, 1994). Another research in Turkey confirms that heavy metals like cadmium, copper, chromium, cobalt, iron, lead, manganese, nickel, and zinc are found in detergent samples from household waste (Soylak et al., 2013).

In Indonesia, the national Water Quality Index (WQI) values indicate poor water conditions; with respect to frequency, 21 provinces have WQI $>60$, but the other seven provinces have WQI $<40$ (Ministry of Environment and Forestry, 2018) WQI is a reference to determine the status of water quality, which, in this country, is part of and has a positive correlation with the composite Environmental Quality Index (EQI). Indonesia is among other countries that have been developing and applying many methods of water quality assessment, which partially reflect government performance in river water quality management. Heavy Metal Pollution Index (HPI) is a form of WQI devoted to determining water quality status based on heavy metal parameters (Abdel-Satar et al., 2017; Edet \& Offiong, 2002; Giri \& Singh, 2014; Prasad \& Bose, 2001). HPI has not been widely applied in the country, especially for rivers receiving a continued discharge of domestic waste. River water quality studies tend to focus on characteristic parameters of domestic waste, such as $\mathrm{pH}, \mathrm{BOD}, \mathrm{COD}, \mathrm{TSS}$, 
ammonia, oil and grease, detergents, and total coliforms (nonmetals), even though the waste can contain heavy metals derived from detergents (Ester Suoth \& Nazir, 2016; Jenkins \& Russell, 1994). Therefore, this research highlights the significance of analyzing Code River's water quality using HPI to assess heavy metal and nonmetal parameters that characterize domestic waste.

\section{RESEARCH METHOD}

The research was conducted in Code River, one of the rivers flowing across three administrative units in the Special Region of Yogyakarta (SRY): Sleman Regency, Yogyakarta City, and Bantul Regency and among those monitored by the regional Environment and Forestry Office (EFO-SRY) every year. This river was selected after considering the year(s) of available data and consistency in the monitored parameters, especially heavy metals, and other characteristic parameters of domestic waste (nonmetals).

The water samples were collected at the observation points predetermined by the EFO-SRY for annual monitoring (three times a year). The research used water quality and discharge data series spanning from 2017 to 2020. This data range is according to the consistency of domestic waste-related heavy metal and nonmetal parameter measurements.

The river water quality was analyzed in three stages. First, the parameter values were compared with the class II water quality standards issued in SRY Governor Regulation No. 20 of 2008. Class II waters are designated as freshwater fish habitats and for water recreation, agricultural irrigation, livestock farming, and other uses with the same requirements. The nonmetal parameters observed were $\mathrm{pH}, \mathrm{BOD}, \mathrm{COD}, \mathrm{NH} 3 \mathrm{~N}$, TSS, total coliforms, and oil and grease, which are regulated in the standards mentioned above. Meanwhile, the heavy metals analyzed were $\mathrm{Fe}, \mathrm{Cu}, \mathrm{Cd}, \mathrm{Cr}$, and $\mathrm{Pb}$. Second, the water quality status was determined using the Heavy Metal
Pollution Index (HPI). Third, the roles of heavy metal and nonmetal parameters in shaping said WQI were compared.

HPI is a water quality index specifically developed to determine the status of water quality based on heavy metal parameters. However, this research examined its application to assessing water quality based on nonmetal parameters. The HPI values were calculated using the formula below (Prasad \& Bose, 2001):

$$
H P I=\frac{\sum_{i=1}^{n} W i Q i}{\sum_{i=1}^{n} W i}
$$

where $W i$ is a weight unit $(1 / \mathrm{Si}), Q i$ is the sub-index of the $i$-th parameter, and $n$ is the number of observed parameters. The HPI values were then categorized into five levels of water qualities: excellent (0-25), good (26-50), poor (51-75), bad (76-100), and unsuitable for drinking (> 100) (Bora \& Goswami, 2017).

The river water quality was evaluated as a whole based on its conditions, status (levels), pollutant sources (land use), and flow rates. Land use types around the monitoring points were identified to determine their direct effects on water quality conditions and levels. Likewise, the analysis considered variations in river flow rates.

\section{RESULTS AND DISCUSSION \\ River Water Quality \\ Heavy Metal Parameters}

Based on the data measurement results (Figure 1a), all heavy metal parameters monitored in this study were generally below their respective upper limits in class II waters. Iron (Fe) levels along the Code River were in the range of $0.13-0.49 \mathrm{mg} / \mathrm{l}$. Elevated irons are caused by changes in redox reaction (reductionoxidation); waters depleted of dissolved oxygen (anoxic) are associated with inflows of high $\mathrm{Fe}$ concentrations into rivers (Kritzberg \& Ekström, 2012).

According to Effendi (2003), low copper $(\mathrm{Cu})$ levels, $<0.02 \mathrm{mg} / \mathrm{l}$, can be found in natural waters. $\mathrm{Cu}$ is extensively 


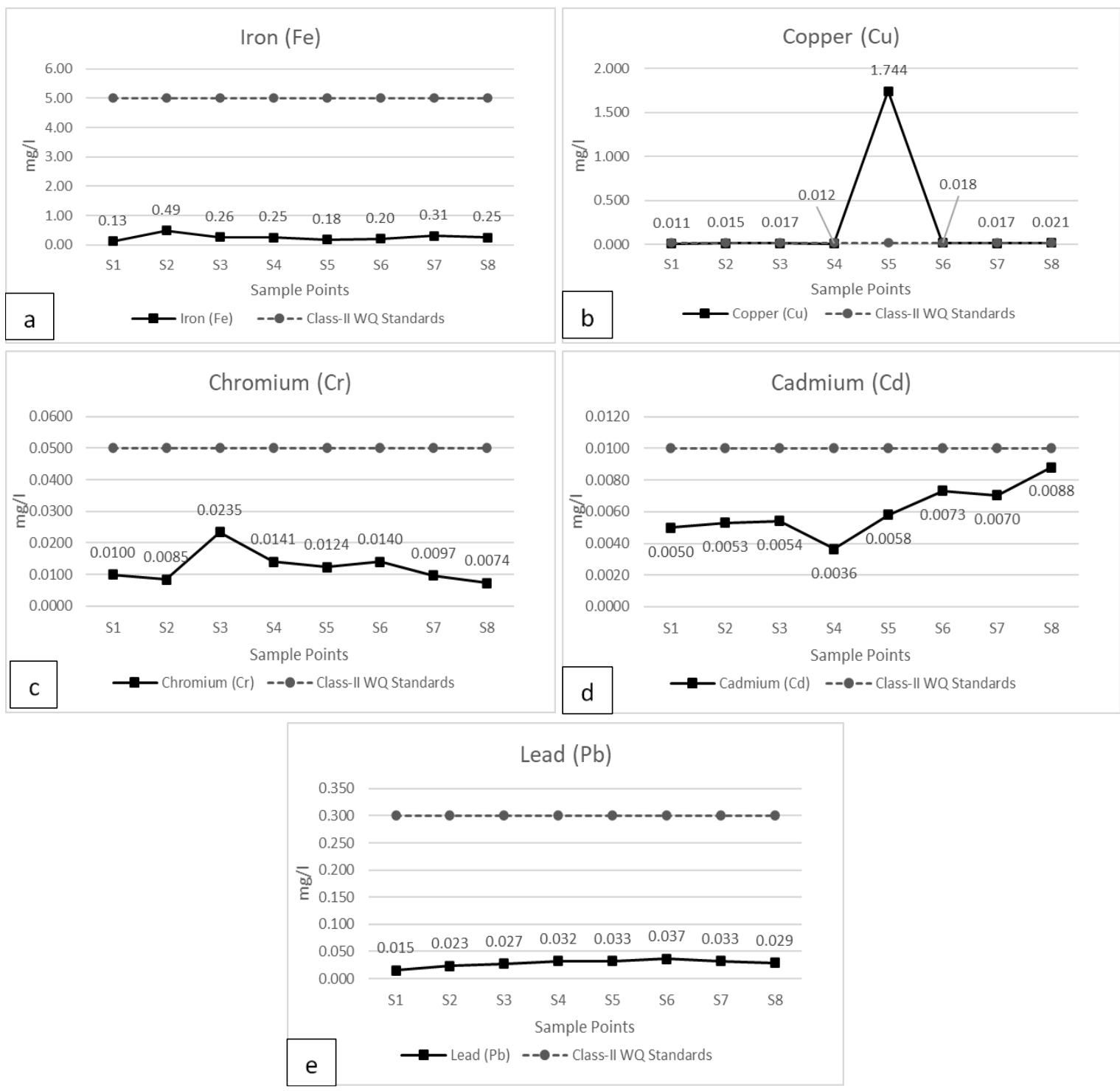

Figure 1. Water Quality of Code River Based on Heavy Metal Parameter Values: a) Iron,

(b) Copper, (c) Chromium, (d) Cadmium, and (e) Lead

Source: Data Analysis, 2021

used in metallurgic, textile, electronics, and paint industries. Like $\mathrm{Fe}, \mathrm{Cu}$ levels along the river met the standards (Figure $1 b$ ), except for monitoring point S5, with $\mathrm{Cu}$ $(1.744<0.02 \mathrm{mg} / \mathrm{l})$ exceeding its maximum allowable presence in class II waters. This point is located on Keparakan Bridge, Mergansan District, downstream of Sinar Obor LLC, a leather tanning industry that uses a mixture of $\mathrm{Cu}$ as the tanning agent (Figure 2). Cadmium (Cd) naturally occurs in minute amounts and is used in, among others, electronics, textile, and leather tanning industries. As presented in Figure $1 c$, the river's $\mathrm{Cd}$ concentrations varied between 0.0036 and $0.0088 \mathrm{mg} / \mathrm{l}$. Compared to other elements, chromium $(\mathrm{Cr})$ is very rarely found in natural waters. However, it is widely used in steel, paint, dye, explosive, textile, glass, and ceramics industries (Kritzberg \& Ekström, 2012). Cr levels at all monitoring points (Figure 1d) were in the range of $0.0074-0.0235 \mathrm{mg} / 1$ or below the upper limit in class II waters, $<0.05$ $\mathrm{mg} / \mathrm{l}$. Lead $(\mathrm{Pb})$ contents only slightly varied, thus creating a horizontal pattern from $\mathrm{S} 1$ to $\mathrm{S} 8$ (Figure 2). As seen in Figure 1e, $\mathrm{Pb}$ was found at its lowest concentration at S1 (0.015 $\mathrm{mg} / \mathrm{l})$ and the highest at $\mathrm{S6}(0.037 \mathrm{mg} / \mathrm{l})$. 


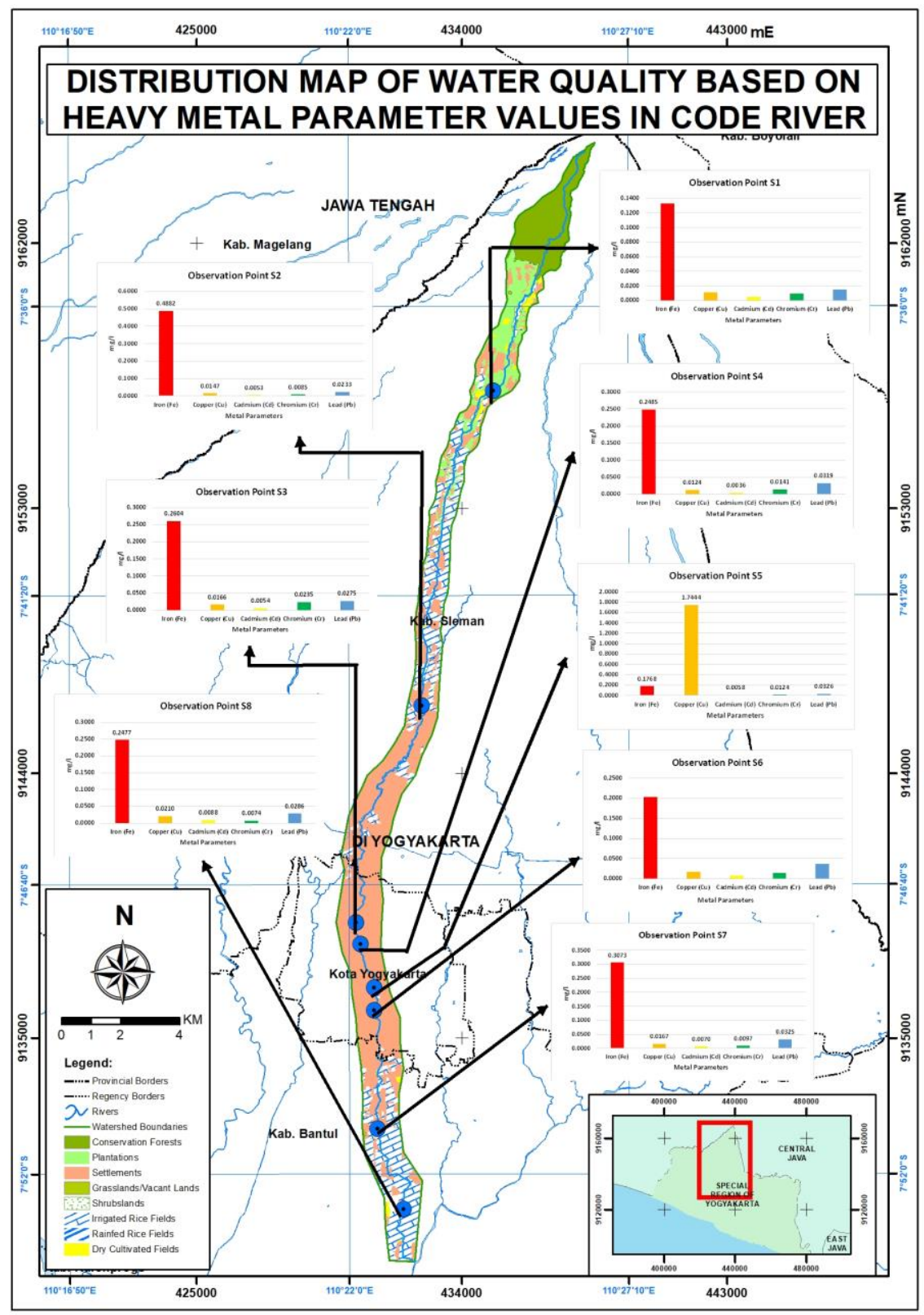

Figure 2. Distribution Map of the Water Quality of Code River Based on Heavy Metal Parameter Values

Source: Data Analysis, 2021

Figure 2 shows that generally, there was a change in the concentration of each heavy metal parameter. The parameter values tended to increase with distance to the headwaters. This finding is in line with a study of heavy metal contents in Tembi River in that the average concentrations are higher in the upper than the lower course (Shanbehzadeh et al., 2014). The figure also shows that iron $(\mathrm{Fe})$ was the most commonly found element along the Code River. Its concentration increased significantly starting from point S3 to S8, which is attributable to settlements (domestic waste sources) around this segment. The amount of oxygen content in the river controls redox reactions that likely lead to such changes in concentration.

Nonmetal Parameters

These parameters are domestic waste properties that are consistently monitored by the EFO-SRY, namely Biological Oxygen Demand (BOD), Chemical Oxygen Demand (COD), ammonia, Total Suspended Solids (TSS), 


\section{"gè@ grafi}

total coliforms, and oil and grease. BOD describes the amount of oxygen taken by anaerobic microbes to oxidize organic material into carbon dioxide and water (Cornwell \& Davis, 1998). It also serves as an indicator of contamination by organic and inorganic matters in a water body. In Code River, the BOD ranged from 3.18 to $23.24 \mathrm{mg} / 1$ (Figure 3a), indicating that the upper limit for BOD in class II waters (i.e., $3 \mathrm{mg} / \mathrm{l}$ ) is exceeded at all measuring points. As seen in Figure $3 a$, BOD fluctuated significantly from one point to the next. It was the lowest at S2 (3.18 mg/l), the river's upper course, and quadrupled to 16.07 $\mathrm{mg} / 1$ at S3 and reached its highest level, $23.24 \mathrm{mg} / 1$, at S5. Elevated BOD in this
Available at http://jurnal.unimed.ac.id/2012/index.php/geo e-ISSN: 2549-7057 | p-ISSN: 2085-8167

segment (S3-S5) is attributable to the inflow of household waste from nearby densely populated settlements in Yogyakarta City (see Figure 4). This finding corresponds with a study in Kalpakkam, India, which demonstrates an increase in BOD in the summer due to untreated input from anthropogenic activities (Kumar \& Reddy, 2009). However, BOD was identified at relatively low levels at $\mathrm{S} 4(12.27 \mathrm{mg} / \mathrm{l})$ and S6 (6.14 mg/l).

Chemical Oxygen Demand (COD) ranged from 11.74 to $54.70 \mathrm{mg} / 1$ (Figure $1 \mathrm{~b})$. COD of water samples at S3, S5, S7, and S8 did not meet the class II water quality standard. Figure $3 \mathrm{~b}$ illustrates how COD fluctuated from one measuring point to the
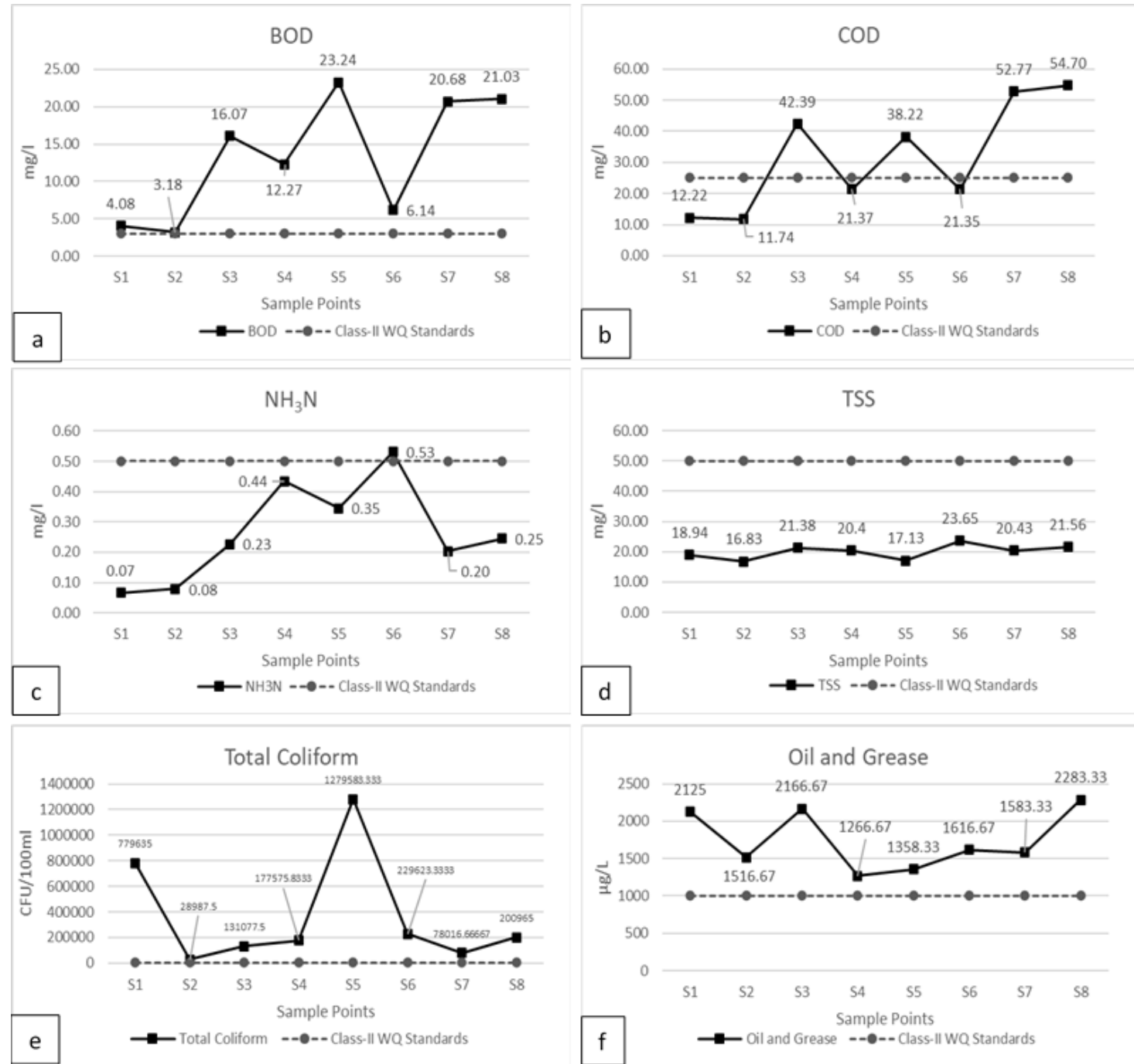

Figure 3. Water Quality of Code River Based on Nonmetal Parameter Values: (a) BOD, (b) COD, (c) $\mathrm{NH}_{3} \mathrm{~N}$, (d) TSS, (e) Total Coliforms, and (f) Oil and Grease Source: Data Analysis, 2021 
next. Like the BOD pattern, COD was the lowest at S1 and S2 and quadrupled at S3. In other words, when the river flows from S2 to S3, it receives an elevated amount of domestic waste generated by densely populated areas in the city. Organic material released into the river is believed to be the cause of said increase (Öztürk et al., 2016).

Ammonia $\left(\mathrm{NH}_{3} \mathrm{~N}\right)$ was detected in the Code River (0.07-0.53 mg/1), with only water samples collected at S6 indicating exceeded upper limit for its presence in class II waters, i.e., $0.53>0.50 \mathrm{mg} / \mathrm{l}$. Spatially, the further the monitoring point from headwaters, the higher the ammonia content (Figure 3c). Like BOD and COD, ammonia levels started to increase downstream of S2 at the river segment located in densely populated settlements (S2-S3). High ammonia contents indicate contamination by organic matters from

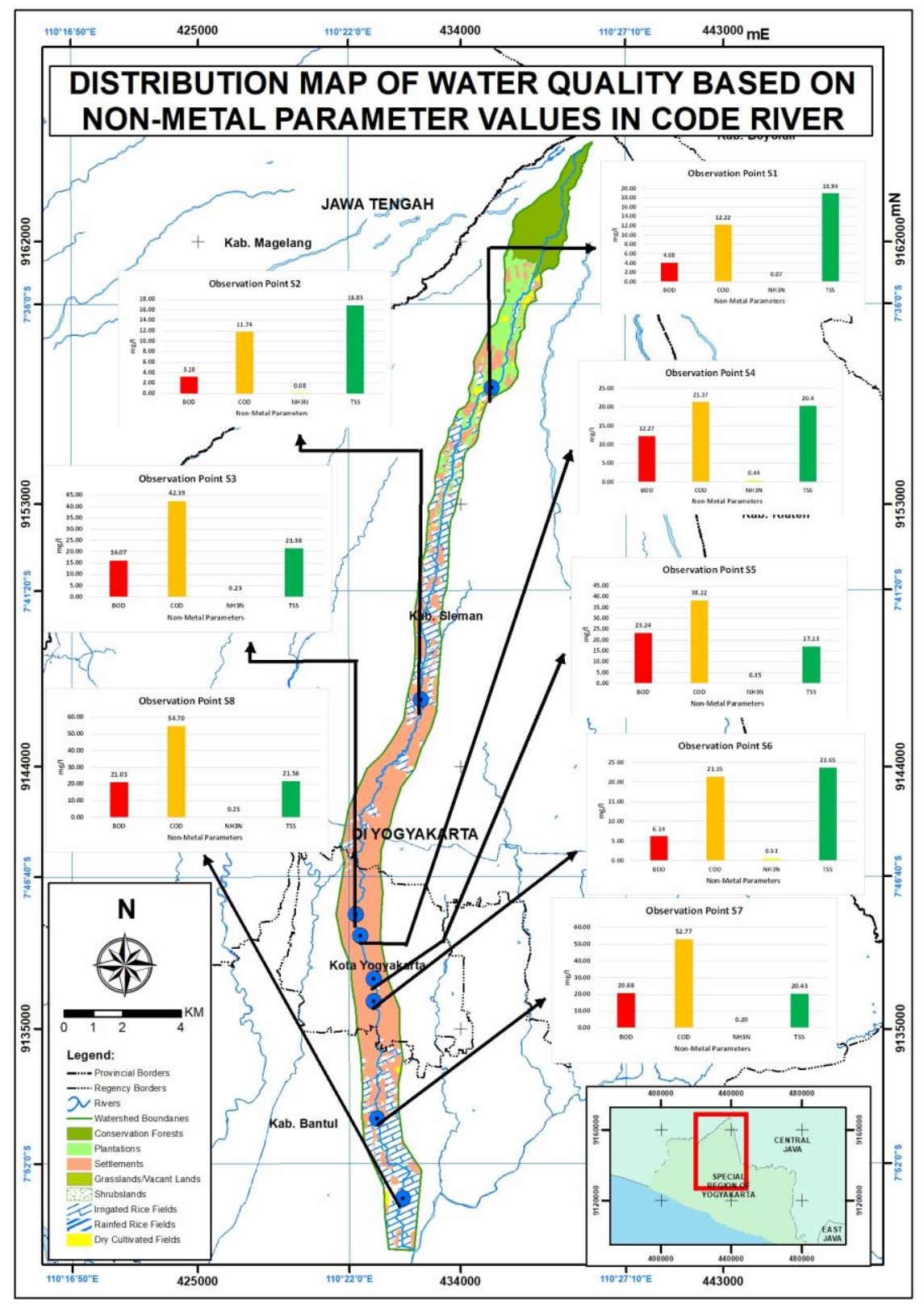

Figure 4. Distribution Map of Water Quality of Code River Based on Nonmetal Parameter Values

Source: Data Analysis, 2021 


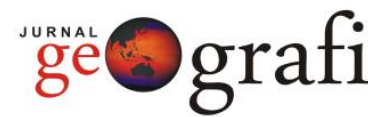

domestic and industrial waste and surface runoffs that transport agricultural fertilizer residues downstream (Effendi, 2003).

The measurement results showed that Code River had Total Suspended Solids (TSS) ranging from 16.83 to 23.65 $\mathrm{mg} / \mathrm{l}$, far below its upper limit in class II waters $(50 \mathrm{mg} / \mathrm{l})$. TSS did not fluctuate as widely as the other nonmetal parameters but slightly increased as the river flowed downstream (Figure 3d). TSS has a positive correlation with turbidity; the higher the TSS, the higher the turbidity value.

There were very high counts of total coliforms in Code River (28,987.5$1,279,583.3$ MPN per $100 \mathrm{ml}$ ), thus exceeding the predefined upper limit for this parameter. The distribution pattern (Figure 3e) shared similarity with other nonmetal parameters in that the counts fluctuated from one measuring point to another. The highest count was detected at S5. These results indicate contamination with effluents from municipal sewage.

Oil and grease are parameters of low biodegradability (Eljaiek-Urzola et al., 2019). Household waste from cooking and residues from industrial activities are sources of these pollutants. Oil and grease were detected along Code River in the range of 1266-2283 $\mu \mathrm{g} / 1$ (Figure 3f), with the highest and lowest concentrations at S8 and S4, respectively. These figures are above the maximum allowable presence of oil and grease in class II waters, $1000 \mu \mathrm{g} / 1$.

In general, the water quality distribution shows that all nonmetal parameter values increase with distance to headwaters (Figure 4). The most significant climb started from S3 to S8 due to the influence of land use distribution in Code Watershed. The areas around S3, S4, S5, and $\mathrm{S6}$ are mainly occupied by dense settlements, the largest source of domestic waste in the watershed.

Land use variations play a substantial role in shaping surface water quality (Adeola Fashae et al., 2019). The upper course of Code River is mainly covered with forests and plantations, and some are used as rice fields. Meanwhile, rice fields and settlements are common in the middle part of the watershed. The lower course is developed for agricultural and residential purposes. Based on the areal percentage, the top three land uses in the watershed are settlements $(50.19 \%)$, followed by irrigated rice fields $(25.21 \%)$ and conservation forests $(10.98 \%)$ (Table 1$)$.

Table 1. Land Use Types and Areas in Code Watershed

\begin{tabular}{lrr}
\hline \multicolumn{1}{c}{ Land Uses } & \multicolumn{1}{c}{$\begin{array}{c}\text { Area } \\
\text { (Ha) }\end{array}$} & $\begin{array}{r}\text { Percentage } \\
\text { (\%) }\end{array}$ \\
\hline Emplacements & 20.01 & 0.45 \\
Conservation Forests & 492.54 & 10.98 \\
Industrial Buildings & 1.39 & 0.03 \\
Settlements & 2252.09 & 50.19 \\
Freshwater Ponds & 2.20 & 0.05 \\
Plantations & 424.42 & 9.46 \\
Rivers & 59.76 & 1.33 \\
Irrigated Rice Fields & 1131.37 & 25.21 \\
Dry Cultivated & & \\
Fields & 56.90 & 1.27 \\
Grasslands/Vacant & & \\
Lands & 2.59 & 0.06 \\
Shrublands & 43.35 & 0.97 \\
Rainfed Rice Fields & 0.43 & 0.01 \\
$\quad$ Total & 4487.07 & 100 \\
\hline
\end{tabular}

Source: Data Analysis, 2021

Residential buildings in urban environments strongly influence and are positively associated with nitrogen and ammonia contents in waters. Forests are positively associated with DO, TDS, and turbidity but negatively associated with temperature, EC, total phosphate, total nitrogen, ammoniacal nitrogen $\left(\mathrm{NH}_{3}-\mathrm{N}\right)$, and nitrate nitrogen. Meanwhile, irrigated rice fields (agricultural land use) do not significantly affect surface water quality (Ding et al., 2015; Li et al., 2008).

\section{Water Quality Conditions Based on the Heavy Metal Pollution Index (HPI)}

HPI is a water quality index that specifically measures the severity of heavy metal pollution (Abdel-Satar et al., 2017; Edet \& Offiong, 2002; Giri \& Singh, 2014; Prasad \& Bose, 2001). In the current study, HPI was used to assess the water quality status of Code River separately (heavy 
metals and nonmetals) and as a whole (all parameters). Table 2 summarizes the results of the HPI assessment using heavy metal parameters. The HPI values from S1 to S8 ranged between 1.33 and 5.11, with the lowest found at Pacar Bridge and the highest at Kewek Bridge. In terms of water quality status, these figures fell into the category excellent. The same case applies to the mean value of HPI at all points, 2.53. These findings indicate that, based on heavy metal parameters alone, Code River has good water quality. In other studies, high metal concentrations in river waters are caused by the entry of effluents from industrial waste (Mokarram et al., 2020) and the use of detergents in households (Soylak et al., 2013). Therefore, low heavy metal contents along the Code River might indicate that human activities in the watershed generate very few to no heavy metal loads.

Table 3 shows that the HPI values composite of nonmetal parameters varied between the river segments. The lowest HPI (3.72) was identified at Ngentak Bridge, whereas the highest was at
Keparakan Bridge (91.84). Based on the HPI category, the monitoring points at Boyong Bridge $(\mathrm{HPI}=5.12)$ and Ngentak Bridge (3.72) had excellent water quality. On the contrary, samples collected at Kewek Bridge (60.27), Sayidan Bridge (67.93), Tungkak Bridge (61.00), and Abangnoto Bridge (72.42) had poor water quality. The monitoring points at Pacar Bridge (78.06) and Keparakan Bridge (91.84) showed high HPI values, indicating bad water quality. Overall, based on nonmetal parameters, the river water quality is categorically poor. Densely populated settlements concentrated along the river are believed to generate and discharge substantial amounts of domestic waste into the river.

As seen in Table 4, water quality assessment using HPI and both metal and nonmetal parameters at each monitoring point resulted in a better mean value, 3.94 or excellent. It is higher than the mean HPI values for heavy metal parameters, although both fall into the same category. This finding confirms that nonmetals affect the overall water quality status.

Table 2. HPI Values and Water Quality Status of Code River Based on Heavy Metal Parameters

\begin{tabular}{|c|c|c|c|c|}
\hline $\begin{array}{l}\text { Sample } \\
\text { Points }\end{array}$ & Locations & Coordinates & HPI & Categories \\
\hline S1 & Boyong Bridge, Pakem, Sleman & $\begin{array}{l}07^{\circ} 37^{\prime} 27.6^{\prime \prime} \mathrm{S} ; \\
110^{\circ} 23^{\prime} 41.5^{\prime \prime} \mathrm{E}\end{array}$ & 1.84 & Excellent \\
\hline S2 & $\begin{array}{l}\text { Ngentak Bridge, Sariharjo, } \\
\text { Ngaglik, Sleman }\end{array}$ & $\begin{array}{l}07^{\circ} 43^{\prime} 231^{\prime \prime} \mathrm{S} \\
110^{\circ} 23^{\prime} 470^{\prime \prime} \mathrm{E}\end{array}$ & 1.57 & Excellent \\
\hline S3 & $\begin{array}{l}\text { Kewek Bridge, Kotabaru, } \\
\text { Yogyakarta }\end{array}$ & $\begin{array}{l}07^{\circ} 47^{\prime} 22.8^{\prime \prime} \mathrm{S} ; \\
110^{\circ} 22^{\prime} 07.9^{\prime \prime} \mathrm{E}\end{array}$ & 5.11 & Excellent \\
\hline S4 & $\begin{array}{l}\text { Sayidan Bridge, Gondomanan, } \\
\text { Ngupasan, Pakualaman, } \\
\text { Yogyakarta }\end{array}$ & $\begin{array}{l}07^{\circ} 48^{\prime} 089^{\prime \prime} \mathrm{S} \\
110^{\circ} 22^{\prime} 273^{\prime \prime} \mathrm{E}\end{array}$ & 2.94 & Excellent \\
\hline S5 & $\begin{array}{l}\text { Keparakan Bridge, } \\
\text { Mergangsan, Yogyakarta }\end{array}$ & $\begin{array}{l}07^{\circ} 48^{\prime} 367^{\prime \prime} \mathrm{S} \\
110^{\circ} 22^{\prime} 454^{\prime \prime} \mathrm{E}\end{array}$ & 2.55 & Excellent \\
\hline S6 & $\begin{array}{l}\text { Tungkak Bridge, Mergangsan, } \\
\text { Yogyakarta }\end{array}$ & $\begin{array}{l}07^{\circ} 49^{\prime} 007^{\prime \prime} \mathrm{S} ; \\
110^{\circ} 22^{\prime} 455^{\prime \prime} \mathrm{E}\end{array}$ & 2.96 & Excellent \\
\hline S7 & $\begin{array}{l}\text { Abangnoto Bridge, Sewon, } \\
\text { Bantul }\end{array}$ & $\begin{array}{l}07^{\circ} 51^{\prime} 093^{\prime \prime} \mathrm{S} ; \\
110^{\circ} 22^{\prime} 520^{\prime \prime} \mathrm{E}\end{array}$ & 1.92 & Excellent \\
\hline S8 & $\begin{array}{l}\text { Pacar Bridge, Wonokromo, } \\
\text { Pleret, Bantul }\end{array}$ & $\begin{array}{l}07^{\circ} 52^{\prime} 398^{\prime \prime} \mathrm{S} \\
110^{\circ} 23^{\prime} 000^{\prime \prime} \mathrm{E}\end{array}$ & 1.33 & Excellent \\
\hline
\end{tabular}


Mean Value (S1-S8)

2.53

Excellent

Source: Data Analysis, 2021

Table 3. HPI Values and Water Quality Status of Code River Based on Nonmetal Parameters

\begin{tabular}{|c|c|c|c|c|}
\hline $\begin{array}{l}\text { Sample } \\
\text { Points }\end{array}$ & Locations & Coordinates & HPI & Categories \\
\hline S1 & Boyong Bridge, Pakem, Sleman & $\begin{array}{l}07^{\circ} 37^{\prime} 27.6^{\prime \prime} \mathrm{S} ; \\
110^{\circ} 23^{\prime} 41.5^{\prime \prime} \mathrm{E}\end{array}$ & 5.12 & Excellent \\
\hline S2 & $\begin{array}{l}\text { Ngentak Bridge, Sariharjo, } \\
\text { Ngaglik, Sleman }\end{array}$ & $\begin{array}{l}07^{\circ} 43^{\prime} 231^{\prime \prime} \mathrm{S} \\
110^{\circ} 23^{\prime} 470^{\prime \prime} \mathrm{E}\end{array}$ & 3.72 & Excellent \\
\hline S3 & $\begin{array}{l}\text { Kewek Bridge, Kotabaru, } \\
\text { Yogyakarta }\end{array}$ & $\begin{array}{l}07^{\circ} 47^{\prime} 22.8^{\prime \prime} \mathrm{S} \\
110^{\circ} 22^{\prime} 07.9^{\prime \prime} \mathrm{E}\end{array}$ & 60.27 & Poor \\
\hline S4 & $\begin{array}{l}\text { Sayidan Bridge, Gondomanan, } \\
\text { Ngupasan, Pakualaman, } \\
\text { Yogyakarta }\end{array}$ & $\begin{array}{l}07^{\circ} 48^{\prime} 089^{\prime \prime} \mathrm{S} \\
110^{\circ} 22^{\prime} 273^{\prime \prime} \mathrm{E}\end{array}$ & 67.93 & Poor \\
\hline S5 & $\begin{array}{l}\text { Keparakan Bridge, } \\
\text { Mergangsan, Yogyakarta }\end{array}$ & $\begin{array}{l}07^{\circ} 48^{\prime} 367^{\prime \prime} \mathrm{S} \\
110^{\circ} 22^{\prime} 454^{\prime \prime}\end{array}$ & 91.84 & Bad \\
\hline S6 & $\begin{array}{l}\text { Tungkak Bridge, Mergangsan, } \\
\text { Yogyakarta }\end{array}$ & $\begin{array}{l}07^{\circ} 49^{\prime} 007^{\prime \prime} \mathrm{S} \\
110^{\circ} 22^{\prime} 455^{\prime \prime} \mathrm{E}\end{array}$ & 61.00 & Poor \\
\hline S7 & $\begin{array}{l}\text { Abangnoto Bridge, Sewon, } \\
\text { Bantul }\end{array}$ & $\begin{array}{l}07^{\circ} 51^{\prime} 093^{\prime \prime} \mathrm{S} ; \\
110^{\circ} 22^{\prime} 520^{\prime \prime} \mathrm{E}\end{array}$ & 72.42 & Poor \\
\hline S8 & $\begin{array}{l}\text { Pacar Bridge, Wonokromo, } \\
\text { Pleret, Bantul }\end{array}$ & $\begin{array}{l}07^{\circ} 52^{\prime} 398^{\prime \prime} \mathrm{S} \\
110^{\circ} 23^{\prime} 000^{\prime \prime} \mathrm{E}\end{array}$ & 78.06 & Bad \\
\hline \multicolumn{3}{|c|}{ Mean Value (S1-S8) } & 55.04 & Poor \\
\hline
\end{tabular}

Source: Data Analysis, 2021.

Table 4. HPI Values and Water Quality Status of Code River Based on Nonmetal and Heavy Metal Parameters

\begin{tabular}{|c|c|c|c|c|}
\hline $\begin{array}{l}\text { Sample } \\
\text { Points }\end{array}$ & Locations & Coordinates & HPI & Categories \\
\hline S1 & Boyong Bridge. Pakem. Sleman & $\begin{array}{l}07^{\circ} 37^{\prime} 27.6^{\prime \prime} \mathrm{S} ; \\
110^{\circ} 23^{\prime} 41.5^{\prime \prime} \mathrm{E}\end{array}$ & 1.93 & Excellent \\
\hline S2 & $\begin{array}{l}\text { Ngentak Bridge. Sariharjo. } \\
\text { Ngaglik. Sleman }\end{array}$ & $\begin{array}{l}07^{\circ} 43^{\prime} 231^{\prime \prime} \mathrm{S} \\
110^{\circ} 23^{\prime} 470^{\prime \prime} \mathrm{E}\end{array}$ & 1.62 & Excellent \\
\hline S3 & $\begin{array}{l}\text { Kewek Bridge. Kotabaru. } \\
\text { Yogyakarta }\end{array}$ & $\begin{array}{l}07^{\circ} 47^{\prime} 22.8^{\prime \prime} \mathrm{S} \\
110^{\circ} 22^{\prime} 07.9^{\prime \prime} \mathrm{E}\end{array}$ & 6.59 & Excellent \\
\hline S4 & $\begin{array}{l}\text { Sayidan Bridge. Gondomanan. } \\
\text { Ngupasan. Pakualaman. } \\
\text { Yogyakarta }\end{array}$ & $\begin{array}{l}07^{\circ} 48^{\prime} 089^{\prime \prime} \mathrm{S} \\
110^{\circ} 22^{\prime} 273^{\prime \prime} \mathrm{E}\end{array}$ & 4.68 & Excellent \\
\hline S5 & $\begin{array}{l}\text { Keparakan Bridge. } \\
\text { Mergangsan. Yogyakarta }\end{array}$ & $\begin{array}{l}07^{\circ} 48^{\prime} 367^{\prime \prime} \mathrm{S} \\
110^{\circ} 22^{\prime} 454^{\prime \prime} \mathrm{E}\end{array}$ & 4.94 & Excellent \\
\hline S6 & $\begin{array}{l}\text { Tungkak Bridge. Mergangsan. } \\
\text { Yogyakarta }\end{array}$ & $\begin{array}{l}07^{\circ} 49^{\prime} 007^{\prime \prime} \mathrm{S} \\
110^{\circ} 22^{\prime} 455^{\prime \prime} \mathrm{E}\end{array}$ & 4.52 & Excellent \\
\hline S7 & $\begin{array}{l}\text { Abangnoto Bridge. Sewon. } \\
\text { Bantul }\end{array}$ & $\begin{array}{l}07^{\circ} 51^{\prime} 093^{\prime \prime} \mathrm{S} \\
110^{\circ} 22^{\prime} 520^{\prime \prime} \mathrm{E}\end{array}$ & 3.81 & Excellent \\
\hline
\end{tabular}


Pacar Bridge. Wonokromo. Pleret. Bantul $07^{\circ} 52^{\prime} 398^{\prime \prime} \mathrm{S}$; $110^{\circ} 23^{\prime} 000^{\prime \prime} \mathrm{E}$
3.39 Excellent

Source: Data Analysis, 2021

\section{Water Quality Evaluation Based on Heavy Metal Pollution Index}

Based on the analysis results, the number of water quality parameters used in the composite HPI determines the final index value. In the case of Code River, the
HPI values calculated solely from heavy metal parameters indicate excellent water quality. In contrast, the ones based on nonmetal parameters illustrate worse conditions in that the water quality status varies from poor to bad to excellent. When both parameters were combined, the

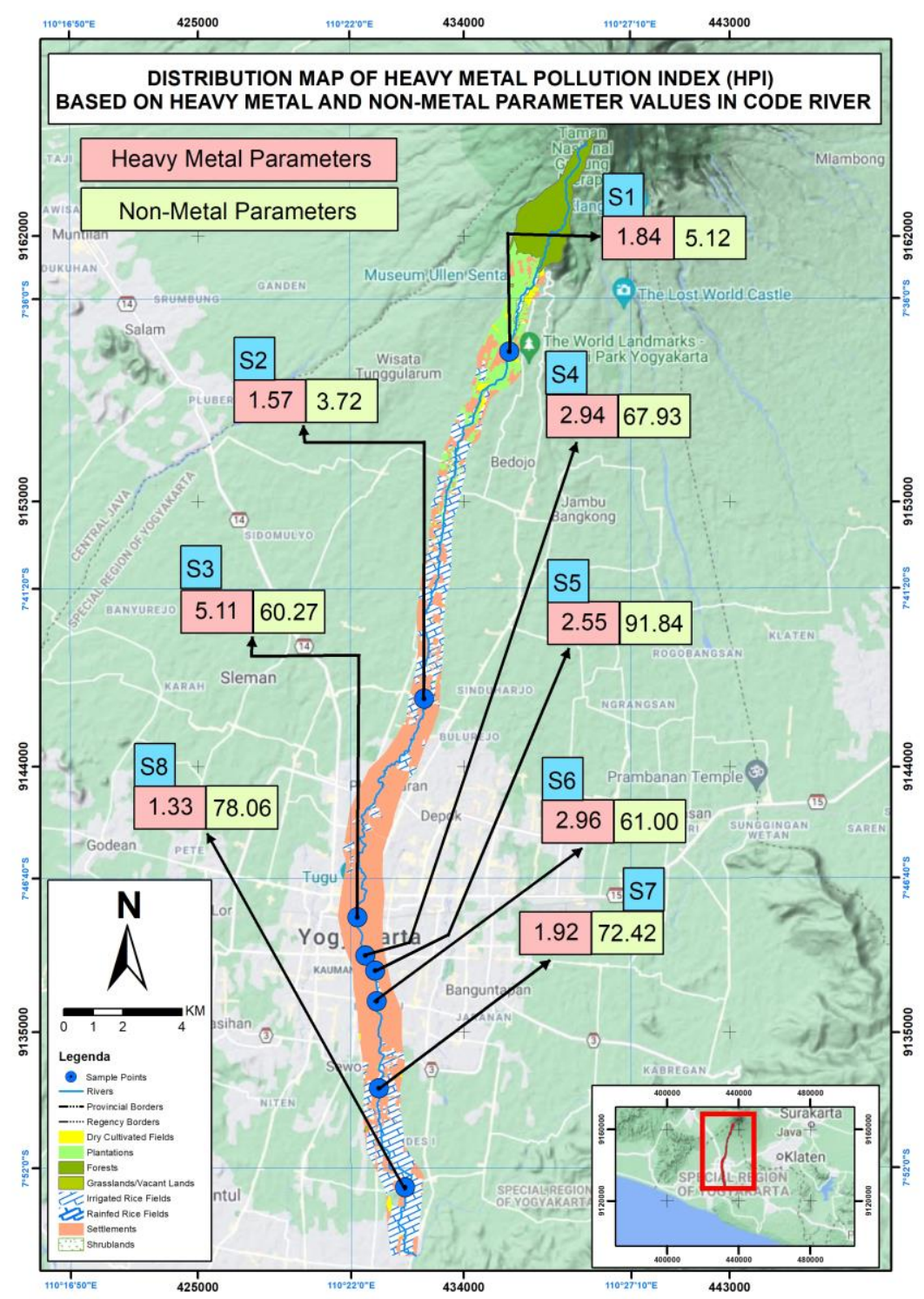

Figure 5. Distribution Map of the Heavy Metal Pollution Index (HPI) Values of Code River Based on Heavy Metal and Nonmetal Parameters Source: Data Analysis, 2021 


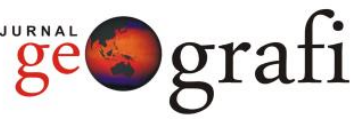

analysis produced lower HPI or excellent water quality. For these reasons, it can be concluded that the more the water quality parameters used in HPI calculation, the higher the chance to obtain better water quality status.

Many methods have been created and improved to calculate the water quality index (WQI) specific to a country's condition. In its development, WQI assessment methods are studied through their applications in various studies. Research work in the Gajahwong River, Yogyakarta, claims that the CCME (Canadian Council of Ministers of the Environment) method performs better than Pollution Index and the Storet method (Saraswati et al., 2014). It is more sensitive in responding to water quality dynamics at each observation location and thus, more universally applied outside Canada.

Variations in discharge and land use in its surroundings influence water quality dynamics at each monitoring point along the Code River. The river segment monitored at $\mathrm{S} 1$ has excellent water quality. It is located in the upper course, which is mainly covered by forests and agricultural fields, and the flow rate was $0.93 \mathrm{~m}^{3} / \mathrm{s}$. Point S2 observes the water quality of a river segment downstream of S1. Here, the transition from agricultural to nonagricultural land utilization starts to appear; most areas along this segment are used as settlements and irrigated rice fields. The flow rate recorded at this point was $0.25 \mathrm{~m}^{3} / \mathrm{s}$. From S3 to S8, the HPI composed of nonmetal parameter values indicates worse water qualities than heavy metals. This finding is attributable to the density of settlements, as the source of domestic waste, that tend to increase downstream. Many densely populated settlements in this segment (S3-S8) potentially contribute to the increased disposal of domestic waste into the river, as indicated by the high HPI values (poor to very bad water qualities). The flow rates observed at these monitoring points were $1.04,1.68,1.58,0.89,0.82$, and $0.94 \mathrm{~m}^{3} / \mathrm{s}$, respectively. Water loss and input of the river systems determine flow rate fluctuations. Based on nonmetal parameters, S5 and S8 have the worst water quality because of the poor sanitation systems in nearby dense settlements. Meanwhile, based on the heavy metal parameter analysis, the water quality at both points is excellent. In other words, the heavy metal loads entering the river system are relatively low. Figure 5 shows the HPI values of each monitoring point based on heavy metal parameters. However, the distribution of these values is not for spatial analysis purposes.

\section{CONCLUSION}

Heavy metal contents of Code River (i.e., $\mathrm{Fe}, \mathrm{Cu}, \mathrm{Cr}, \mathrm{Cd}$, and $\mathrm{Pb}$ ) are below their maximum allowable presence in class II waters, except for S5, whose Cu content has exceeded its upper limit. This is based on the water quality standards issued in the SRY Governor Regulation No. 20 of 2008. The concentrations of nonmetal parameters typical of domestic waste (i.e., BOD, COD, NH3N, TSS, total coliforms, and oil and grease) have exceeded their upper limits, except for TSS that meets the predefined standard.

Based on the heavy metal parameters, the mean HPI value of Code River is 2.53 , indicating excellent water quality, but the one calculated using nonmetal parameters is higher, i.e., 55.04, signifying poor water quality. However, the composite of all parameters shows a much lower HPI, 3.94, that falls into the category of excellent water quality. In this case, water quality status is sensitive to changes in land use, especially from agricultural to non-agricultural lands in the lower course. The effect of discharge variation is deemed insignificant to the water quality parameter values. Furthermore, Code River has better quality based on the HPI values that composite both metal and nonmetal parameters. The more the water quality parameters used to determine HPI, the greater the chance to obtain a better water quality status. 


\section{ACKNOWLEDGMENTS}

This research work is financially supported by the Faculty of Geography, Universitas Gadjah Mada, through the independent lecturer grant scheme sourced from the Community Fund for the fiscal year 2020 .

\section{REFERENCES LIST}

Abdel-Satar, A. M., Ali, M. H., \& Goher, M. E. (2017). Indices of water quality and metal pollution of Nile River, Egypt. Egyptian Journal of Aquatic Research, 43(1), 21-29.

Adeola Fashae, O., Abiola Ayorinde, H., Oludapo Olusola, A., \& Oluseyi Obateru, R. (2019). Landuse and surface water quality in an emerging urban city. Applied Water Science, 9(2), 1-12.

Adhitya, Y., Prasetya, D., \& Rengganis, H. (2017). Pemanfaatan Sumber-sumber Air Untuk Mendukung Irigasi Pertanian Tebu di Kaki Gunung Tambora. Jurnal Teknik Hidraulik, 8(1), 1-15.

Ali, A., Soemarno, \& Purnomo, M. (2013). Kajian Kualitas Air Dan Status Mutu Air Sungai Metro. Jurnal Bumi Lestari, 13(2), 265-274.

Bora, M., \& Goswami, D. C. (2017). Water quality assessment in terms of water quality index (WQI): case study of the Kolong River, Assam, India. Applied Water Science, 7(6), 3125-3135.

Cornwell, D. A., \& Davis, M. L. (1998). Introduction to Environtmental Enginering. Mac-Graw-Hill. Inc.

Ding, J., Jiang, Y., Fu, L., Liu, Q., Peng, Q., \& Kang, M. (2015). Impacts of land use on surface water quality in a subtropical river basin: A case study of the dongiiang river basin, Southeastern China. Water (Switzerland), 7(8), 4427-4445.

Edet, A. E., \& Offiong, O. E. (2002). Evaluation of water quality pollution indices for heavy metal contamination monitoring. A study case from Akpabuyo-Odukpani area, Lower Cross River Basin (southeastern Nigeria). GeoJournal, 57(4), 295-304.
Effendi, H. (2003). Telaah Kualitas Air Bagi Pengelolaan Sumberdaya dan Lingkungan Perairan (1st ed.) Kanisius

Eljaiek-Urzola, M., Romero-Sierra, N., Segrera-Cabarcas, L., ValdelamarMartínez, D., \& Quiñones-Bolaños, É. (2019). Oil and grease as a water quality index parameter for the conservation of marine biota. Water (Switzerland), 11(4).

Ester Suoth, A., \& Nazir, E. (2016). Karakteristik Air Limbah Rumah Tangga Pada Salah Satu Perumahan Menengah Keatas Di Tangerang Selatan. Jurnal Ecolab, 10(2), 80-88.

Giri, S., \& Singh, A. K. (2014). Assessment of Surface Water Quality Using Heavy Metal Pollution Index in Subarnarekha River, India. Water Quality, Exposure and Health, 5(4), 173-182.

Gusril, H. (2016). Studi Kualitas Air Minum PDAM di Kota Duri Riau. Jurnal Geografi, 8(2), 1-7.

Imroatushshoolikhah, Purnama, I. S., \& Suprayogi, S. (2014). Kajian Kualitas Air Sungai Code Propinsi Daerah Istimewa Yogyakarta. Majalah Geografi Indonesia, 28(1), 23-24.

Jenkins, D., \& Russell, L. L. (1994). Heavy metals contribution of household washing products to municipal wastewater. Water Environment Research, 66(6), 805-813.

Kritzberg, E. S., \& Ekström, S. M. (2012). Increasing iron concentrations in surface waters - A factor behind brownification? Biogeosciences, 9(4), 1465-1478.

Kumar, A. Y., \& Reddy, M. V. (2009). Assessment of seasonal effects of municipal sewage pollution on the water quality of an urban canal - A case study of the Buckingham canal at Kalpakkam (India): NO3, PO4, SO4, BOD, COD and DO. Environmental Monitoring and Assessment, 157(1-4), 223-234.

Li, S., Gu, S., Liu, W., Han, H., \& Zhang, Q. (2008). Water quality in relation to land use and land cover in the upper Han River Basin, China. Catena, 75(2), 216222. 
Mahyudin, Soemarno, \& Prayogo, T. B. (2015). Analisis kualitas air dan strategi pengendalian pencemaran air sungai metro di kota kepanjen kabupaten malang. 6(2), 105-114.

Ministry of Environment and Forestry. (2018). Indeks Kualitas Lingkungan Hidup Indonesia Tahun 2017.

Mokarram, M., Saber, A., \& Sheykhi, V. (2020). Effects of heavy metal contamination on river water quality due to release of industrial effluents. Journal of Cleaner Production, 277, 123380.

Öztürk, M., Ashraf, M., Aksoy, A., Ahmad, M. S. A., \& Hakeem, K. R. (2016). Plants, pollutants and remediation. Plants, Pollutants and Remediation, 1404.

Pohan, D. A. S., Budiyono, B., \& Syafrudin, S. (2017). Analisis Kualitas Air Sungai Guna Menentukan Peruntukan Ditinjau Dari Aspek Lingkungan. Jurnal Ilmu Lingkungan, 14(2), 63.

Prasad, B., \& Bose, J. M. (2001). Evaluation of the heavy metal pollution index for surface and spring water near a limestone mining area of the lower himalayas. Environmental Geology, 41(1-2), 183-188.

Saraswati, S. P., Sunyoto, Kironoto, B. A., \& Hadisusanto, S. (2014). Penentuan Status Mutu Perairan Sungai Tropis di Indonesia (Assessment of the Forms and Sensitivity of the Index Formula PI, Storet, CCME for The Determination of Water Quality Status of A Tropical Stream in Indonesia). Jurnal Manusia Dan Lingkungan, 21(2), 129-142.

Shanbehzadeh, S., Vahid Dastjerdi, M., Hassanzadeh, A., \& Kiyanizadeh, T. (2014). Heavy metals in water and sediment: A case study of Tembi River. Journal of Environmental and Public Health, 2014.

Soylak, M., Unsal, Y. E., \& Tuzen, M. (2013). Evaluation of metal contents of household detergent samples from Turkey by flame atomic absorption spectrometry.

Environmental Monitoring and Assessment, 185(11), 9663-9668. 